\title{
NÄKEEKÖ YMPÄRISTÖJOURNALISTI METSÄÄ PUILTA?
}

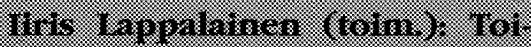

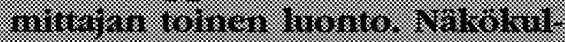
Min.

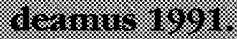

$\mathbf{L}$ ukijaa ärsyttää heti vähän se, ettei nimiösivulta käy ilmi kustantaja, takakannesta kyllä. Vain siellä myös kerrotaan, että kyseessä on 70-vuotiaan Suomen Sanomalehtimiesten Liiton juhlakirja. Vaatimattomuutta vai suutarin akan kengättömyyttä editoinnissa? Sisältö sinänsä on tärkeä ja kiinnostava, mutta jonkin verran epätasainen.

Johdannossa ei määritellä, mitä ympäristöjournalismi on. Urheilusta kirjoittamista ei useinkaan sanota urheilujournalismiksi, senkö takia, että urheilutoimittaja niin vähän pohtii urheiluun liittyviä arvoja? Hän on ensi sijassa selostaja. Ympäristöjournalismi ei kirjan aihevalikoiman ja artikkelien sisällön perusteella ole pelkkää ympäristöstä kirjoittamista. Aleksanterinkadun ihmisvilinän kuvailija ei liene ympäristöjournalisti. Ympäristötoimittaja on ilmeisesti henkilö, joka suhtautuu myönteisesti ympäristöön, mutta taloustoimittaja ei välttämättä ole henkilö, joka suhtautuu myönteisesti talouteen. Hyvä taloustoimittaja on ensi sijassa kriittinen.

Määrittely voi olla tylsää ja hedelmätöntäkin, mutta sitä kannattaa aina yrittää. Jo yrityskin selkeyttää ajatuksia. "Ympäristöjournalismissa ei ole kysymys näkökulman supistamisesta", johdannossa sanotaan. Seuraava lause onkin jo julistusta: "Päinvastoin, näkökulmaa on nykyisestä avarrettava." Tarkoitus on hyvä, mutta jour- nalismin rajausten ja julistuksen limittyminen saa lukijan epäröiväksi.

$\mathbf{T}$ oimitta(i)n kunniaksi on sanottava, ettei valikoima ole yksisilmäinen. Joukossa on varsin kriittistä tekstiä: "Ympäristöjournalismi ei ole salainen lähetystehtävä" (Ismo Tuormaa), "- yksittäisissä tapauksissa suomalainen ympäristöjournalismi on asiantuntevaa, mutta kokonaisuutena vääristävää, epäsystemaattista ja pinnallista" (Kaarina Melakoski erääseen pro gradu -työhön vedoten), ”Tämä (iltapäivälehtien) ympäristöjournalismi on yhtä epä-älyllistä kuin 1970-luvun taistolaisuus toimittajamaailmassa" (Aarno Laitinen).

Kirjan toinen jakso, "Toimittajan maastokelpoisuus", käsittää lyhyitä tapausselostuksia aiheista, jotka takavuosina ovat olleet esillä. Osa niistä on käsitelty pintapuolisesti ja edelleen kovin kampanjoivasti, vaikka etäisyyttä olisi jo riittävästi pohtivampaankin journalismiin. Ehkä juttujen mittaa on rajoitettu liiaksi. Tämä osasto ei ole kirjan parasta antia.

Kolmas jakso "Jutun juurilla" sisältää ansiokkaita katsauksia. Mainitsen vain Markku Ollikaisen artikkelin "Taloudellinen kasvu, saastuminen ja kannustimet ympäristönsuojelussa", Olli Järvisen "Suomen ympäristöuhat 2017" ja Jorma Laurilan "Luonto on aina sodan uhri". Sen sijaan Leena Vilkan filosofia ei vakuuttanut minua yhtään: "Ihmisen itseisarvo perustuu siihen, että hänellä on oma hyvänsä." Tässä kaivattaisiin Lutheria, ei uskon puhdistamiseksi vaan selittämiseksi. Ihmisarvo tulee kristinuskosta, ei taivaasta. Nokkoseen ei satu, kun niitän sen, niin uskon. Mutta myönnän, että "ihminen voi hankkia tietoa eliöiden hyvästä", ehkä myös nokkosen tuntemuksista. 
$\mathbf{T}$ uormaa vaatii artikkelissaan taloustoimittajien, poliittisten toimittajien ja ympäristötoimittajien tiimityötä. Näyttääkin siltä, että tiedottajat ovat tavoittamassa yhä useampia ammattikuntia, saamassa yhteyden heihin ja heidän välilleen, mutta yksi ammattikunta on edelleen paitsiossa: insinöörit. Koska nämä yhteiskunnan rengit on jo nyt asetettu ja asetettavissa yhä enemmän myös ympäristönsuojelutehtäviin, lähinnä alan tekniikan kehitystyöhön, olisi varmaan itse ympäristönsuojelulle eduksi, jos heillekin palautettaisiin heille kuuluva ihmisarvo. Jos kohta heitä ei kirjassa enää parjatakaan, ei myöskään muisteta tuoda esiin esimerkiksi Suomessa kehitettyä veden ja ilman puhdistamistekniikkaa, sen merkitystä kotimaisen teollisuuden osana ja myös yhä lisääntyvässä määrin vientituotteena.

$\mathbf{Y}$ mpäristöjournalismi ja valtarakenteet on jäänyt vähälle huomiolle. Se onkin varmaan arka aihe monille alan kirjoittajille, sillä siksi ikäviä tietoja olisi käytettävissä edesmenneestä proletariaatin diktatuurista idässä. Antti Halkka tuntuu tietävän, miten kunnallispoliitikon tulisi ympäristöasioissa käyttäytyä äänestäjiensä edessä, kun hän toteaa alaviitteessä: "Toki se toi julkisuuteen sen hämmästyttävän ylimielisen tavan, jolla kunnallispoliitikot tässä maassa suhtautuvat kuntalaisten elinympäristöön". Saattaa kuitenkin olla, että "ylimielisyys" kuntatasolla kertoo vain itse kuntalaisten asioiden tärkeysjärjestyksestä: ensin leipä sitten ympäristö!

Toimittajien tekstien lukijoissa on kriittisiä kansalaisia, sellaisia, jotka haluavat säilyttää luontoa ja luonnonvaroja lapsille ja lastenlapsille. Mutta heidän karvansa nousevat pystyyn, kun kampanjointi hyvän asian puolesta yritetään pukea pitävää tietoa jakavan journalismin kaapuun. Tämä kirjanen erittelee journalismin ilmiöitä tavalla, jonka uskon edistävän ekologisesti kestävämmän sivistysihanteen asiaa laajalla rintamalla. Juttujen lyhyyden takia kirja saattaa löytää lukijoita myös toimittajien piirissä.

$\mathbf{Y}$ mpäristöjournalismin kuten monen muunkin alueen "journalismin" avainkysymys on, jaksaako toimittaja hankkia sen asiatietojen määrän, jota onnistuminen alueella vaatii. Pelkkä tieteenharjoittajien haastattelu ja heihin tur- vaaminen ei riitä, koska tutkijan selkänojana oleva tieteellinen tieto poikkeaa struktuuriltaan olennaisesti arkikokemukseen perustuvasta tiedosta, eikä monikaan tutkija pysty yleistajuistamisen keinoin siirtämään oman rakenteensa aineksia maallikon maailmankuvaan sopiviksi. Toimittajan on osattava kysyä siten, ettei tutkija voi vetäytyä oman tiedonstruktuurinsa määräämän kielenkäytön turvasatamaan. Tosin tutkijaa ei voi vaatia antamaan vastausta kysymykseen, johon tieteellä ei vielä ole vastausta, ja tähän on toimittajankin tyytyminen. Tiedettä ei tehdä sen takia, että sanomalehtien sivut täyttyisivät.

Kirjan kokoaminen ja julkaiseminen osoittaa toimittajien halua päästä journalismin keskeisellä lohkolla entistä parempaan tulokseen. Kirjassa vaaditaan, että metsänhoitoa olisi ruvettava sanomaan puunhoidoksi, koska vain puu eikä metsäkokonaisuus on "hoitajien" kiinnostuksen kohteena. Journalistit alkavat nähdä puut metsältä. 